\title{
Systematics of Eidothea (Proteaceae), with the description of a new species, E. hardeniana, from the Nightcap Range, north-eastern New South Wales
}

\author{
Peter H. Weston and Robert M. Kooyman
}

\begin{abstract}
Weston, P.H. ${ }^{1}$ and Kooyman, R. ${ }^{2}$ ('National Herbarium of New South Wales, Royal Botanic Gardens, Sydney, NSW 2000, Australia; ${ }^{2}$ Earth Process Ecological Services, 220 Dingo Lane, Myocum, NSW 2482, Australia) 2002. Systematics of Eidothea (Proteaceae), with the description of a new species, E. hardeniana, from the Nightcap Range, north-eastern New South Wales. Telopea 9(4): 821-832. Eidothea hardeniana P.H. Weston \& R.M. Kooyman, a new species from the Nightcap Range, New South Wales, is named and described and its collection history discussed. The only other species of Eidothea, E. zoexylocarya, is also redescribed and the two species are compared. The morphology, phylogeny, classification, biogeography and character phylogeny of Eidothea are also briefly discussed.
\end{abstract}

\section{Introduction}

In October 2000 we collected fertile material of an unnamed species of the genus Eidothea (Proteaceae), from the Nightcap Range in north-eastern New South Wales. In this paper we name it E. hardeniana, as well as redescribing its sister species, E. zoexylocarya, and the genus as a whole. We also discuss its collection history, phylogenetic relationships, and aspects of its morphology.

The Nightcap Eidothea was probably first collected in 1953 by L.J. Webb and J.G. Tracey, as part of their ecological survey of Whian Whian State Forest. Their specimen is sterile, with spinose-dentate juvenile foliage. They identified it as Lomatia arborescens (Proteaceae), which it superficially resembles, differing most obviously in its pseudoverticillate phyllotaxis. The specimen was sent to BRI, where it was incorporated into the herbarium collection. It was redetermined in 1979 as an unnamed species of Corynocarpus (Corynocarpaceae).

A similar specimen, bearing no information other than 'coppice leaves', was sent by H.C. Hayes to BRI, apparently at a later date. This was also incorporated into the herbarium, and was labelled 'H.C. Hayes, Coffs Harbour'. This specimen was matched with that of Webb and Tracey, and determined as Corynocarpus sp.

Coffs Harbour, however, is unlikely to be the true collection locality. Alex Floyd (in litt.) writes of Hayes:

Harold Hayes was my botanical assistant here at Coffs Harbour from 1956 until his retirement about 20 years later. He was an authority on field identification of New South Wales rainforest trees and was in great demand for field trips with C.T. White, Laurie Johnson, Lyn Pryor and Len Webb. Trees named after him include Endiandra hayesii, Melicope hayesii and Symplocos hayesii (North Queensland). Harold lived here in Coffs Harbour, but our area extended from the Hawkesbury River to the Queensland border. Harold had a special love for Whian Whian State Forest and made many collections from there. I have no doubt that this was where he collected the Eidothea specimen. Possibly he sent it up from Coffs Harbour to his good friend Lindesay Smith at the Brisbane Herbarium for identification. 
The Nightcap Eidothea then went uncollected until 1988, when one of us (RMK) found similar juvenile material in Nightcap National Park. In August 2000, RMK discovered mature trees and collected basal subsidiary shoots, wood, and gnawed fruits, which he sent to NSW for identification. The wood displayed the wide rays characteristic of most members of the Proteaceae and the fruit structure was so similar to that of the recently described Eidothea zoexylocarya (Douglas \& Hyland 1995a, b) that both of us concluded that it must be a species of Eidothea. Adult, flowering material that we collected in October 2000 further confirmed the generic identity of this species and allowed detailed comparison with Eidothea zoexylocarya. This led us to conclude that although the Nightcap Eidothea closely resembles E. zoexylocarya, it is morphologically distinct from it.

\section{Morphology}

Douglas and Hyland (1995b) deal succinctly with the morphology of Eidothea but a few supplementary comments are necessary.

Firstly, the fruit is not a 'nut', contrary to Douglas and Hyland's description. Recently published botanical English glossaries (e.g. McCusker, 1981: 183, Harden 2002: 650) define a nut as a dry, indehiscent fruit formed from two or more carpels but containing only one seed. Since the flower of Eidothea possesses only one carpel (as do all Proteaceae) the fruit cannot be a nut, according to this definition. Older English and German botanical literature (e.g. Bentham 1863, Troll 1957) defines 'nut' more broadly to include dry fruits developed from a single carpel. However, In both species of Eidothea the pericarp is differentiated into three layers: a thin epidermis, a softly fleshy but not very succulent mesocarp, and a hard, bony inner layer. The term 'drupe' has usually been used for such fruits, although it has also been applied inconsistently (see Clifford \& Dettmann 2001 for a recent review of usage of the term 'drupe'). For example, some definitions restrict its use to fruits in which the inner bony layer, the endocarp, develops exclusively from the inner epidermis of the carpel, while other definitions are based on the anatomy of the mature fruit, regardless of organogeny (Clifford and Dettmann 2001). Since fruit organogeny is known for a only a minority of taxa, the latter class of definitions is much more widely applicable than the former. Clifford and Dettmann (2001) conclude their discussion by proposing a definition of the term 'drupe', based solely on gross anatomy. Under this definition, the fruit of Eidothea is a drupe and this is the terminology that we have adopted.

In both species the inflorescence axis is a flattened receptacle on which sessile flowers are crowded. Mature inflorescences consist of one or two central flowers, one of which is sometimes bisexual (the others being male), surrounded by a false whorl of male flowers. Many of the inflorescences of both species that we have examined are wholly male, having no bisexual flower. Douglas and Hyland (1995b:127) describe the inflorescence of E. zoexylocarya as 'a capitulate raceme' and 'forming condensed racemes, usually one flower perfect, the others male'. Although detailed developmental study of inflorescences of E. zoexylocarya (Andrew Douglas pers. comm.) corroborates this interpretation, some additional qualifying comments based on our dissections of mature inflorescences are necessary. Firstly, Douglas and Hyland (1995b: 127) state that the flowers are 'solitary in each bract axil'. However, we could find no bracts subtending the central flower(s) in either species and they are presumably so reduced in the mature inflorescence as to be functionally absent. They are very much smaller than the prominent bracts that subtend the outer false whorl of flowers. Similarly, we could find no terminal bud at or near the centre of the inflorescence in either species, although Andrew Douglas (pers. comm.) has observed the presence of 'a residuum of the inflorescence apex' in developing inflorescences of E. zoexylocarya. Given their close similarity, the structure and development of the inflorescence of E. hardeniana is most likely to correspond to that of E. zoexylocarya. 
In other respects, the inflorescence of E. hardeniana appears to differ significantly from that of E. zoexylocarya, although attached to this assertion is the caveat that we have been able to make a detailed examination of floral material from only one tree of E. hardeniana. The majority of bisexual flowers of E. hardeniana that we have examined have 5 tepals. Some of these flowers are truly 5-merous, having five stamens; others, however, have only four stamens, one of which is inserted between two of the tepals. All of the flowers of E. zoexylocarya that we have examined have been 4-merous.

\section{Phylogeny, Classification, Biogeography and Character Phylogeny}

Douglas and Hyland (1995a, b) erected a new monogeneric subfamily for Eidothea on the grounds that 'The combination of plesiomorphic and apomorphic features suggests that Eidothea represents a new subfamily, one possibly leading to the line of Proteoideae' (Douglas \& Hyland 1995b: 128). However, a subsequent molecular systematic analysis (Hoot \& Douglas 1998), based on chloroplast DNA sequence data, showed that Eidothea is nested within the subfamily Proteoideae. Moreover, it is more closely related to all but two genera of Proteoideae, than any of them are to Agastachys and Symphionema. This clade received $85 \%$ bootstrap support in Hoot and Douglas's analysis of their 'combined' data set. The Eidotheoideae thus renders the Proteoideae paraphyletic as presently circumscribed. The simplest taxonomic change that would solve this problem would be inclusion of Eidothea in the subfamily Proteoideae.

The strict consensus from Hoot and Douglas's 'combined' data set places Eidothea as part of a trichotomy at the node above the base of the Proteoideae. One of the other two clades that branch from this node includes two subclades that span the Indian Ocean. If the Proteaceae really is a Gondwanic taxon (see e.g. Weston \& Crisp 1996), then these subclades date back to the rifting of Africa from the rest of Gondwana, about 100 million years ago (Pitman et al. 1993). The age of the more basal Eidothea lineage would then be older than this.

Hoot and Douglas's (1998) results allow us to reassess the homology and polarity of characters in Eidothea within a corroborated phylogenetic framework. Character states such as pseudoverticillate phyllotaxis and, longitudinal ribs on the inner surface of the endocarp are unique in the Proteoideae and are thus clearly interpretable as generic synapomorphies (sensu Hennig 1966). Andromonoecy (sensu Walker \& Whelan 1991) is rare in the Proteoideae, being otherwise known only in Stirlingia (Connell \& Ladd 1994, McCarthy 1995), but this is most parsimoniously interpreted as having arisen independently of andromonoecy in Eidothea. This condition can therefore be tentatively added to the list of generic synapomorphies.

Differences between the two species of Eidothea are mostly much more difficult to resolve as autapomorphies, given the size and morphological diversity of the relevant outgroups. A tendency in E. hardeniana to produce 5-merous bisexual flowers might, on further sampling, prove to be the only unequivocal autapomorphy.

\section{Eidothea A.W. Douglas \& B. Hyland}

Douglas and Hyland (1995a: 472); Douglas and Hyland (1995b: 127).

Type species: Eidothea zoexylocarya A.W. Douglas \& B. Hyland

Andromonoecious trees. Bark grey, compact. Trichomes simple. Shoots composed of a succession of repeated growth units, each consisting of a basal false internode and a terminal false whorl of leaves; false internodes bearing numerous spirally inserted scale leaves which are crowded, imbricate, persistent and broad-ovate to orbicular at the base, becoming uncrowded, mostly caducous and narrow-triangular more distally; false whorls bearing (2-)3-17 crowded, spirally inserted leaves. Leaves simple, the 
undersurface paler than the upper surface; juvenile leaves with dentate or entire margins; adult leaves entire. Inflorescence a lateral, axillary or ramiflorous, shortly pedunculate capitulate raceme, with one or two central, vestigially bracteate flowers, one of which may be bisexual, surrounded by a false whorl of prominently bracteate male flowers, with narrow tufts of erect trichomes arising from the axis between the flowers. Flowers with tepals becoming circinate at anthesis; male flowers usually slightly asymmetrical due to slight compression and incurving at the base, but otherwise actinomorphic, 4-merous, with or without a central, sterile gynoecium; bisexual flowers actinomorphic, slightly larger in size than male flowers, 4-merous or sometimes 5-merous (only in E. hardeniana). Tepals free except for a short, basal tube, valvate, approximately oblong in shape but slightly constricted at the tip of the basal tube and narrowing abruptly to a truncate base and an acute tip, glabrous externally, with long trichomes at base but otherwise glabrous internally, creamy white when fresh. Stamens free or the filaments slightly adnate to the base of the tepals, creamy white, longer than the tepals in bud; filaments filiform, tapered from base to tip, with a sinuous, double fold between the midpoint and the tip in bud, glabrous or with scattered antrorse marginal hairs in the basal half, weak, not supporting the anthers; anthers narrow-oblong, slightly tapered towards tip, latrorsely dehiscent via longitudinal slits, without terminal appendages, of varying orientation; pollen grains triporate. Hypogynous glands absent. Ovary shortly stipitate (merely narrowed towards the base), with ascending hairs; style terete, the tip not modified as a pollen presenter; stigma bilobed; ovule 1, orthotropous, pendulous, longitudinally ribbed. Fruit a drupe, globose to ellipsoidal to pyriform, with a circular depression surrounding the point of attachment, slightly asymmetrical, the style remnant slightly subterminal, with several longitudinal ribs on the inside of the endocarp, corresponding to longitudinal furrows in the seed surface.

\section{Key to the living species}

1 Adult leaves obtuse to acuminate, lacking a spinose mucro; venation more prominent on the abaxial leaf surface than the adaxial; adaxial venation (when dried) with primary vein usually prominently raised, secondary veins obscure to prominently raised, tertiary veins sometimes obscurely evident, quarternary veins obscure; primary and rarely proximal parts of secondary veins cream- to brown-coloured. Floral bracts surrounding inflorescence slightly recurved or incurved. Widest part of perianth tube unthickened. Sterile gynoecium of male flowers absent, or present but with a spathulate, obscurely bilobed tip. Style abruptly tapered at tip, not capitate ..1. Eidothea zoexylocarya

$1^{*}$ Adult leaves acuminate, with a prominent, needle-like, apical spine 1-4.5 mm long; venation more prominent on the adaxial leaf surface than the abaxial; adaxial venation (when dried) with primary to quarternary veins prominently raised, primary, secondary and proximal parts of tertiary veins cream-coloured. Floral bracts surrounding inflorescence strongly recurved to revolute. Widest part of perianth tube distinctly thickened. Sterile gynoecium of male flowers with a prominently bifid tip. Style tip prominently capitate 2. Eidothea hardeniana 


\section{Eidothea zoexylocarya A.W. Douglas \& B. Hyland}

Douglas and Hyland (1995a: 473); Douglas and Hyland (1995b: 128).

Type: Queensland: Cook: Timber Reserve 1230, Boonjee Logging Area, Mt Bartle Frere, Qld, 9 Jan 1980, B. Gray 1611 (holo QRS (not seen); iso MEL!, BRI, CANB, DNA, HO, K, L, LSU, MO, NSW, PERTH, PRE, QRS).

Trees 20-40 m high, with one main trunk 40 to $80 \mathrm{~cm}$ diameter at breast height, lacking subsidiary basal shoots. Bark ash-grey, flaky with pale, irregular or round lenticels. False internodes $5.0-9.5 \mathrm{~cm}$ long in juvenile shoots, $(0.8-) 1.5-10.2 \mathrm{~cm}$ long in adult shoots. Scale leaves of false internodes basally persistent, c. $0.75-1.7 \mathrm{~mm}$ long, $1.0-1.5 \mathrm{~mm}$ wide, distally mostly caducous, to $3.5 \mathrm{~mm}$ long, $0.9 \mathrm{~mm}$ wide. Juvenile leaves (plants to $1.5 \mathrm{~m}$ high) in false whorls of $3-5$, elliptical to narrow-elliptical, entire or innocuous-dentate to spinose-dentate, $6.0-12.0 \mathrm{~cm}$ long, $2.5-4.7 \mathrm{~cm}$ wide; petiole $8-13 \mathrm{~mm}$ long; margins entire or with up to 7 teeth, with spines to $2.5 \mathrm{~mm}$ long, flat to recurved; tip acuminate or spinose-acuminate with apical spine to $2.5 \mathrm{~mm}$ long. Adult leaves in false whorls of $4-7$, mostly obovate to oblanceolate or occasionally spathulate or elliptical, (1.3-)6.8-16.0 cm long, (0.4-)1.8-6.4 cm wide; petiole (2-)8-15 mm long; margins entire, usually recurved to revolute, especially towards the base; apical spine absent. Leaf venation brochidodromous or occasionally with three primary veins in adult leaves, more prominent on the abaxial leaf surface than the adaxial when dried; primary vein prominently raised on both surfaces but more prominent on the abaxial surface, cream to brown on abaxial surface, contrasting with the colour of the rest of the abaxial lamina, distally cream to brown on adaxial surface but proximally the same colour as the rest of the adaxial lamina; secondary veins prominently to obscurely evident on the adaxial surface, more prominently raised on the abaxial surface, usually the same colour as the rest of the lamina; tertiary veins usually obscure on adaxial surface, slightly raised, the same colour as the rest of the lamina on abaxial surface; quarternary veins obscure on both surfaces. Inflorescences axillary, 6-10-flowered; peduncle 3.0-6.5 mm long. Floral bracts ovate to oblong-ovate with truncate base and acute to obtuse or rounded tip, slightly recurved or incurved, $1.4-3.5 \mathrm{~mm}$ long, 0.6-2.2 $\mathrm{mm}$ wide. Male flowers with perianth $8.7-11.0 \mathrm{~mm}$ long; basal tubular part of perianth 2.3-3.2 mm long, $0.5-1.0 \mathrm{~mm}$ wide at base, dilating to $1.8-1.9 \mathrm{~mm}$ wide at widest point $1.0-1.2 \mathrm{~mm}$ from base, usually narrowing to $1.7-1.9 \mathrm{~mm}$ wide at tip; free tepal tips oblonglanceolate, abruptly tapering to an acute tip, $6.0-7.8 \mathrm{~mm}$ long, $1.6-1.8 \mathrm{~mm}$ wide; staminal filaments $5.3-5.8 \mathrm{~mm}$ long, $0.3 \mathrm{~mm}$ wide at base, $0.2 \mathrm{~mm}$ wide at the tip; anthers 4.0-4.5 mm long, 0.9-1.0 mm wide; sterile gynoecium absent or present and \pm linear but swollen towards tip, terete, with a spathulate, obscurely bilobed tip, $4.8 \mathrm{~mm}$ long, $0.5 \mathrm{~mm}$ wide at base, $0.7 \mathrm{~mm}$ wide at tip, with a tuft of antrorse hairs at base. Hermaphrodite flowers with perianth 10.2-11.0 mm long; basal tubular part of perianth $3.0-3.8 \mathrm{~mm}$ long, $1.0-1.1 \mathrm{~mm}$ wide at base, dilating to $2.1-2.2 \mathrm{~mm}$ wide at widest point $1.2-1.3 \mathrm{~mm}$ from base, narrowing to $1.7-1.8 \mathrm{~mm}$ wide at tip; free tepal tips oblong-lanceolate, abruptly tapering to an acute tip, c. $7.2 \mathrm{~mm}$ long, $1.5-1.8 \mathrm{~mm}$ wide; staminal filaments tapered towards tip, glabrous or with scattered antrorse marginal hairs in the basal half, 5.2-5.8 mm long, 0.3-0.5 mm wide at base, $0.2 \mathrm{~mm}$ wide at the tip; anthers not measured; gynoecium 9.2-9.3 mm long; ovary 2.3-2.5 mm long, 1.1-1.3 mm wide, with 4 dense tufts of ascending hairs in alternitepalous positions; style terete, $6.7-7.0 \mathrm{~mm}$ long, $0.8-1.0 \mathrm{~mm}$ wide, with an abruptly tapered, bilobed stigma. Fruits globose or ovoid, 3.5-6.0 cm long, 3.0-6.5 cm diameter (Douglas \& Hyland 1995b). 
Distribution: headwaters of the Mulgrave, Russell and Bloomfield Rivers, northeastern Queensland.

Habitat: complex mesophyll vine forest to simple notophyll vine forest on metamorphics or granite, at altitudes from 600-1460 metres.

Phenology: flowering from January to March; fruits take about one year to develop.

Conservation status: 'vulnerable if not endangered' according to Douglas and Hyland (1995b: 128) but B. Hyland (pers. comm.) argues that since populations discovered after 1995 have greatly increased the number of known plants, this species should no longer be considered to be endangered. It is known from several conservation reserves.

Selected specimens (from 10 examined): Queensland: Cook: Mt Bartle Frere, NW peak, State Forest Reserve 755, B. Gray 3952, 4 Mar 1985 (MEL, NSW); Mt Bartle Frere, S slope, above boulder field, A.W. Douglas 666 \& B. Gray, 22 May 1996 (MEL); SW slope of Mt Bartle Frere, B.G. Briggs 7416, 1 Sep 1983 (BRI, NSW); State Forest Reserve 755, Boonjee Logging Area, Mt Bartle Frere, B. Hyland 12475, 24 Jan 1983 (MEL, NSW); Wooroonooran National Park, track to Combo Creek, P.I. Forster 23986, R. Jensen, \& R. Booth, 27 Nov 1998 (BRI, MEL).

\section{Eidothea hardeniana P.H. Weston $\mathcal{E}$ Kooyman, sp. nov.}

Arbores andromonoeciae. Folia adulta acuminata, spina apicali prominenti aciculari 1-4.5 mm longa; venatio prominentior supra, in sicco venis adaxialibus primariis usque ad quaternariis prominentibus; venae primariae ad secundariae et partes proximales venarum tertiariorum cremicolores. Bracteae florales valde recurvae vel revolutae. Pars latissima perianthii manifeste incrassata. Gynoecium sterile florum marium apice perspicue bifido. Apex styli manifeste capitatus.

Type: New South Wales: North Coast: Nightcap Range, P.H. Weston 2469, R. Johnstone, R. Kooyman $\mathcal{E}$ J. Hunter, 26 Oct 2000 (holo NSW 446591; iso AD, BRI, CANB, HO, K, MEL, MO, NE, NSW 445873, QRS).

Trees 15-40 m high, with one main trunk to $70 \mathrm{~cm}$ diameter at breast height, but often with up to 40 smaller subsidiary shoots with stems $0.5-10 \mathrm{~cm}$ diameter, branching from the base. Bark on stems $>30 \mathrm{~cm}$ diameter ash grey, with pale irregular horizontally flattened lenticels giving the impression of horizontal crinkling. False internodes $4.5-16 \mathrm{~cm}$ long in juvenile shoots, $8-77 \mathrm{~cm}$ long in basal subsidiary shoots, $2-13 \mathrm{~cm}$ long in adult shoots. Scale leaves of false internodes basally persistent, c. $0.7-1.0 \mathrm{~mm}$ long, 0.7-1.0 mm wide, distally mostly caducous, to $2.5 \mathrm{~mm}$ long, $1 \mathrm{~mm}$ wide. Juvenile leaves (plants 1-1.5 m high) in false whorls of 3-6, narrowly elliptical to oblanceolate or lanceolate, with spinose-dentate margins, $8-15 \mathrm{~cm}$ long, 2-5 cm wide; petiole $4-8 \mathrm{~mm}$ long; margins flat to slightly recurved, with 9-20 teeth, each bearing a spine 1-4 mm long; apical spine 1-4 mm long. Leaves of basal subsidiary shoots in false whorls of $2-17$, elliptical to obovate or narrowly so, with spinose-dentate margins in basal false whorls, becoming entire in more distal false whorls, 9-18 cm long, 2.3-5.4 cm wide; petiole 4-11 mm long; margins flat to slightly recurved, with up to 20 teeth, each bearing a spine 1.5-4 mm long; apical spine 1-6 mm long. Adult leaves in false whorls of 4-7, narrowly elliptical to oblanceolate, with entire, flat to slightly recurved margins, (2.5-)8-13.5 cm long, (0.7-)1.7-4.2 cm wide; petiole (3-)5-10 mm long; apical spine $1-4.5 \mathrm{~mm}$ long. Leaf venation brochidodromous, more prominent on the adaxial leaf surface than the abaxial when dried; primary vein prominently raised on both surfaces but more prominent on the abaxial surface, cream; secondary veins prominently raised on both surfaces but more prominent on the adaxial surface, cream; tertiary veins prominently raised, proximally cream, distally green on adaxial surface, slightly raised, green on abaxial surface; quarternary veins slightly raised, green on adaxial surface, slightly raised or obscure, green on abaxial surface. Inflorescences axillary or ramiflorous, 7-11-flowered; peduncle 6-7 $\mathrm{mm}$ long. Floral bracts spathulate to 


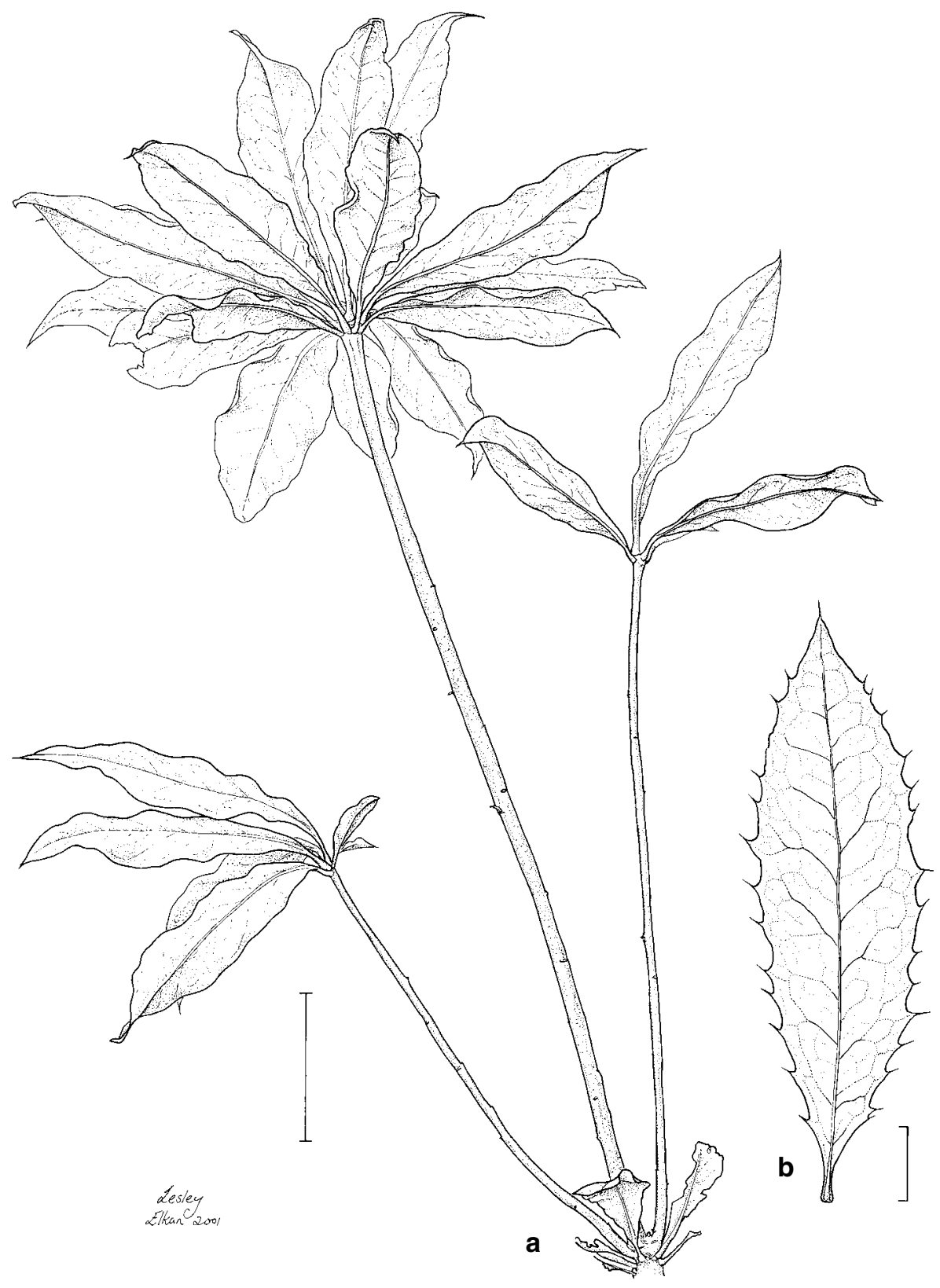

Fig. 1. Eidothea hardeniana P.H. Weston \& R.M. Kooyman. a, terminal part of basal subsidiary shoot; b, juvenile leaf. a from Weston 2464 et al., b from Weston 2471 et al. Scale bar: $a=6 \mathrm{~cm} ; \mathrm{b}=1.5 \mathrm{~cm}$. 


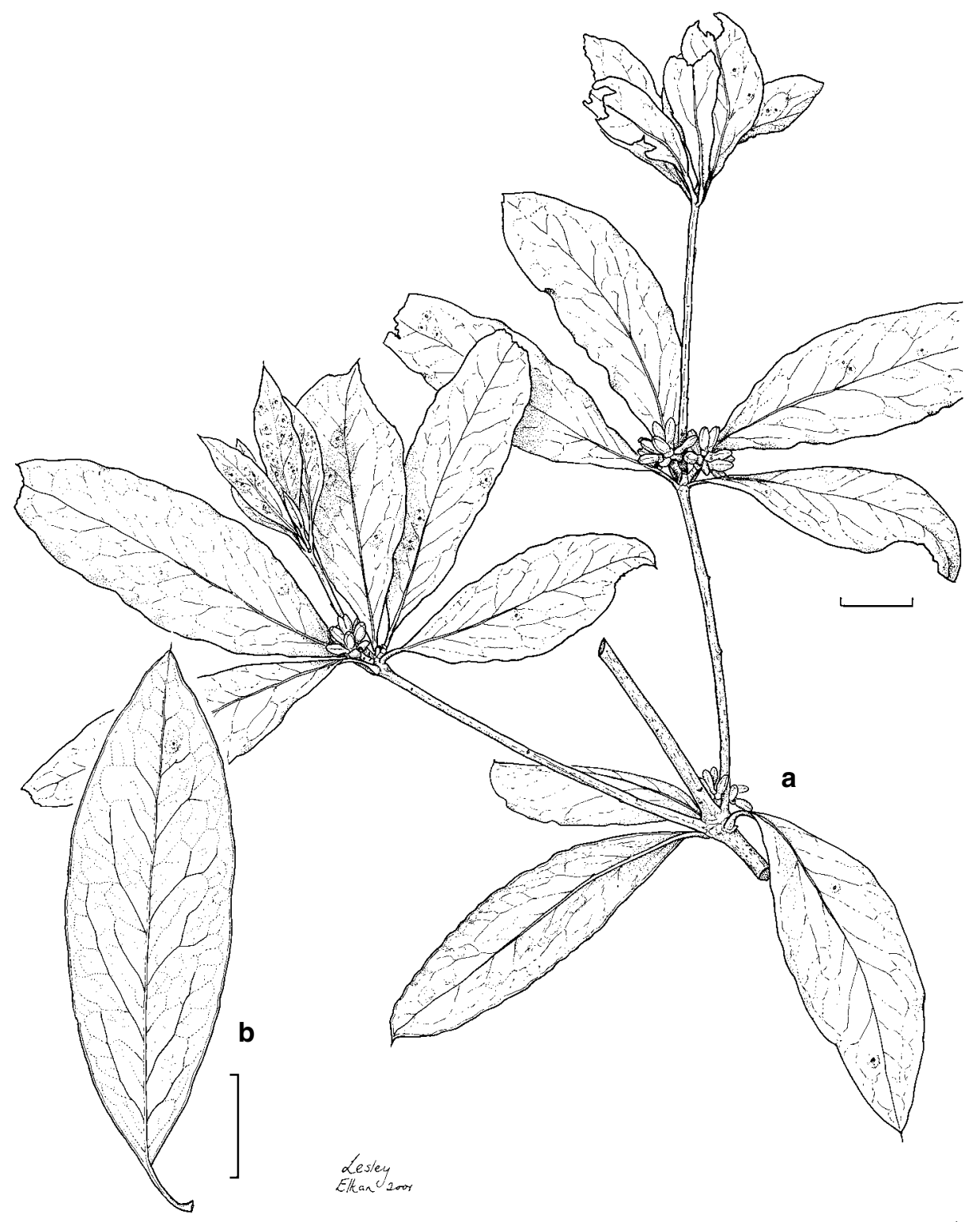

Fig. 2. Eidothea hardeniana P.H. Weston \& R.M. Kooyman. a, flowering shoot; b, adult leaf. From Weston 2469 et al. Scale bar: a, b $=2 \mathrm{~cm}$. 
oblanceolate with truncate base and obtuse to rounded tip, strongly recurved to revolute, 5.1-5.5 mm long 2.4-3.0 mm wide. Male flowers with perianth $8.0-9.6 \mathrm{~mm}$ long; basal tubular part of perianth $2.2-3.3 \mathrm{~mm}$ long, $0.9-1.0 \mathrm{~mm}$ wide at base, dilating to a thickened ring $1.3-2.0 \mathrm{~mm}$ from base, $2.6-3.0 \mathrm{~mm}$ wide at widest point, narrowing to 1.6-2.2 mm wide at tip; free tepal tips oblong-lanceolate, abruptly tapering to an acute tip, 5.0-6.3 $\mathrm{mm}$ long, 1.6-1.9 mm wide; staminal filaments tapered from base to tip, glabrous or with scattered antrorse marginal hairs in the basal half, $3.7-6.5 \mathrm{~mm}$ long, $0.35-0.5 \mathrm{~mm}$ wide at base, $0.25-0.3 \mathrm{~mm}$ wide at the tip; anthers $4.0-5.0 \mathrm{~mm}$ long,1.1-1.4 mm wide; sterile gynoecium linear, terete, with a prominently bifid tip, $4.7 \mathrm{~mm}$ long, $0.2 \mathrm{~mm}$ wide, with scattered antrorse hairs at base. Hermaphrodite flowers with perianth 10.0-12.0 mm long; basal tubular part of perianth $3.4 \mathrm{~mm}$ long, $1.2-1.7 \mathrm{~mm}$ wide at base, dilating to a thickened ring $2.6 \mathrm{~mm}$ from base, $3.8-3.9 \mathrm{~mm}$ wide at widest point, narrowing to $2.3-2.7 \mathrm{~mm}$ wide at tip; free tepal tips oblonglanceolate, abruptly tapering to an acute tip, $6.6-7.2 \mathrm{~mm}$ long, $1.7-1.8 \mathrm{~mm}$ wide; staminal filaments tapered from base to tip, glabrous or with scattered antrorse marginal hairs in the basal half, $4.2-8.0 \mathrm{~mm}$ long, $0.5 \mathrm{~mm}$ wide at base, $0.3 \mathrm{~mm}$ wide at the tip; anthers 4.9-5.0 mm long, $1.2 \mathrm{~mm}$ wide; gynoecium 9.5-10.6 mm long; ovary 2.3-2.7 mm long, 1.4-2.2 mm wide, densely covered in ascending hairs; style terete, $7.2-7.9 \mathrm{~mm}$ long, $0.8 \mathrm{~mm}$ wide, with a prominently capitate, bilobed stigma. Fruits broad-ovoid to broad-ellipsoidal, $3.5-4.0 \mathrm{~cm}$ long, 3.0-3.7 cm diameter, green maturing to dull golden yellow; epidermis c. $0.08 \mathrm{~mm}$ thick; mesocarp 2-4 mm thick, composed of soft, pithy, cream-coloured tissue, separating readily from the endocarp; pyrene broadovoid to broad-ellipsoidal, with a rounded base and sharply pointed tip, $2.7-3.4 \mathrm{~cm}$ long, 2.3-3.1 cm wide; endocarp bony, brown, with a slightly rough surface, $2.5-4 \mathrm{~mm}$ thick; internal longitudinal ribs to $3 \mathrm{~mm}$ high, $2 \mathrm{~mm}$ wide. (Figs 1-4).

Distribution: restricted to a single catchment on the southern side of the Nightcap Range in north-eastern New South Wales.

Habitat: upland cool and riparian simple notophyll vine forest (to notophyll vine forest) on acid volcanics (rhyolite lithology). Dominant tree species include Ceratopetalum apetalum, Endiandra introrsa, Canarium australasicum, Schizomeria ovata, Austrobuxus swainii, Cinnamomum oliverii, sometimes with occasional emergents including Lophostemon confertus, Callitris macleayana, or Tristaniopsis collina.

Phenology: flowering from mid-October to mid-November; fruits take over one year to develop, reaching full size in about mid December, then changing colour from green to dull yellow over the following two to three months, falling from mid-February to early March.

Conservation status: listed as 'Eidothea sp. 'Nightcap Range' (P.H. Weston 2469)' in New South Wales as an endangered species on Schedule 1 of the Threatened Species Conservation Act, 1995. This species is known to occur in Nightcap National Park and in the adjacent Whian Whian State Forest. Ninety-two trees with diameter at breast height greater than $10 \mathrm{~cm}$, and 76 seedling plants, were discovered in surveys conducted by RMK to May 2001.

Derivation of name: named in honour of our friend and colleague Gwen J. Harden, whose career has been devoted to improving our knowledge of the flora of New South Wales, particularly of the State's rainforest plants.

Specimens examined: New South Wales: North Coast: Nightcap Range, P.H. Weston 2464, 2466-2469, 2471, R. Johnstone, R.M. Kooyman \& J. Hunter, 26 Oct 2000 (NSW); Nightcap Range, R.M. Kooyman s.n., 25 Aug 2000 (NSW) 444188; Nightcap Range, R.M. Kooyman s.n., Nov 2000 (NSW) Nightcap Range, R.M. Kooyman s.n., Dec 2000 (NSW 478642); Nightcap Range, P.H. Weston 2550, R.M. Kooyman \& P. Bernhardt, 5 Nov 2001 (NSW, NE); Whian Whian State Forest, L.J. Webb \& J.G. Tracey, 1953 (BRI 37567); Locality unknown, H.C. Hayes, date unknown (BRI 226481). 

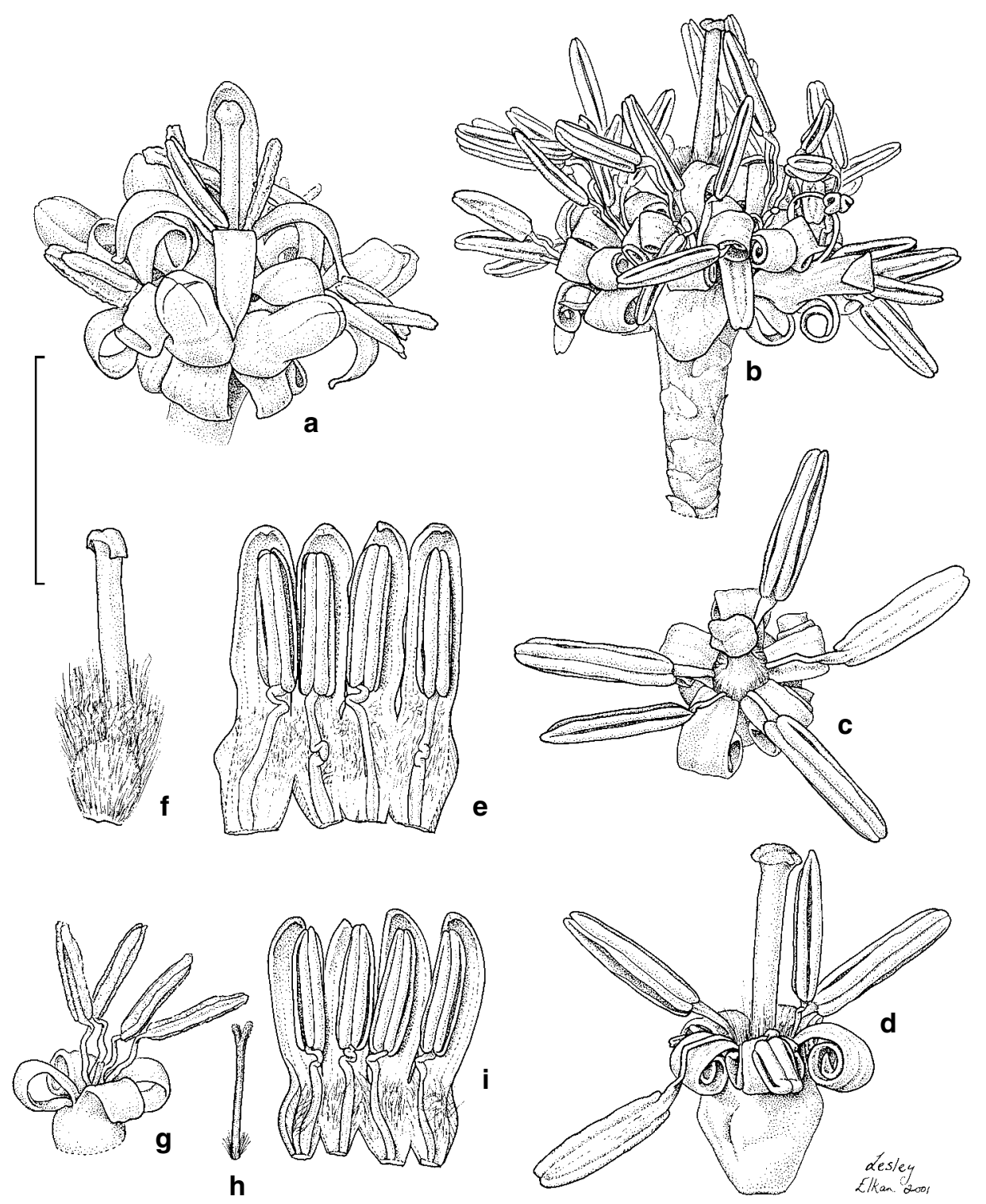

Fig. 3. Eidothea hardeniana P.H. Weston \& R.M. Kooyman. a, inflorescence with flower buds starting to open, showing the central hermaphrodite flower surrounded by a false whorl of bracteate male flowers; $\mathbf{b}$, inflorescence of open flowers; $\mathbf{c}, 5$-merous hermaphrodite flower, viewed from above; d, 5-merous hermaphrodite flower, viewed from the side; e, 4-merous hermaphrodite flower, opened, showing perianth and stamens; $\mathbf{f}$, gynoecium of hermaphrodite flower; $\mathbf{g}$, male flower, viewed from the side; $\mathbf{h}$, sterile gynoecium of male flower; $\mathbf{i}$, male flower, opened, showing perianth and stamens. From Weston 2469 et al. Scale bar: a, b, g = $10 \mathrm{~mm} ; \mathrm{c}-\mathrm{f}, \mathrm{h}, \mathrm{i}=7.5 \mathrm{~mm}$. 

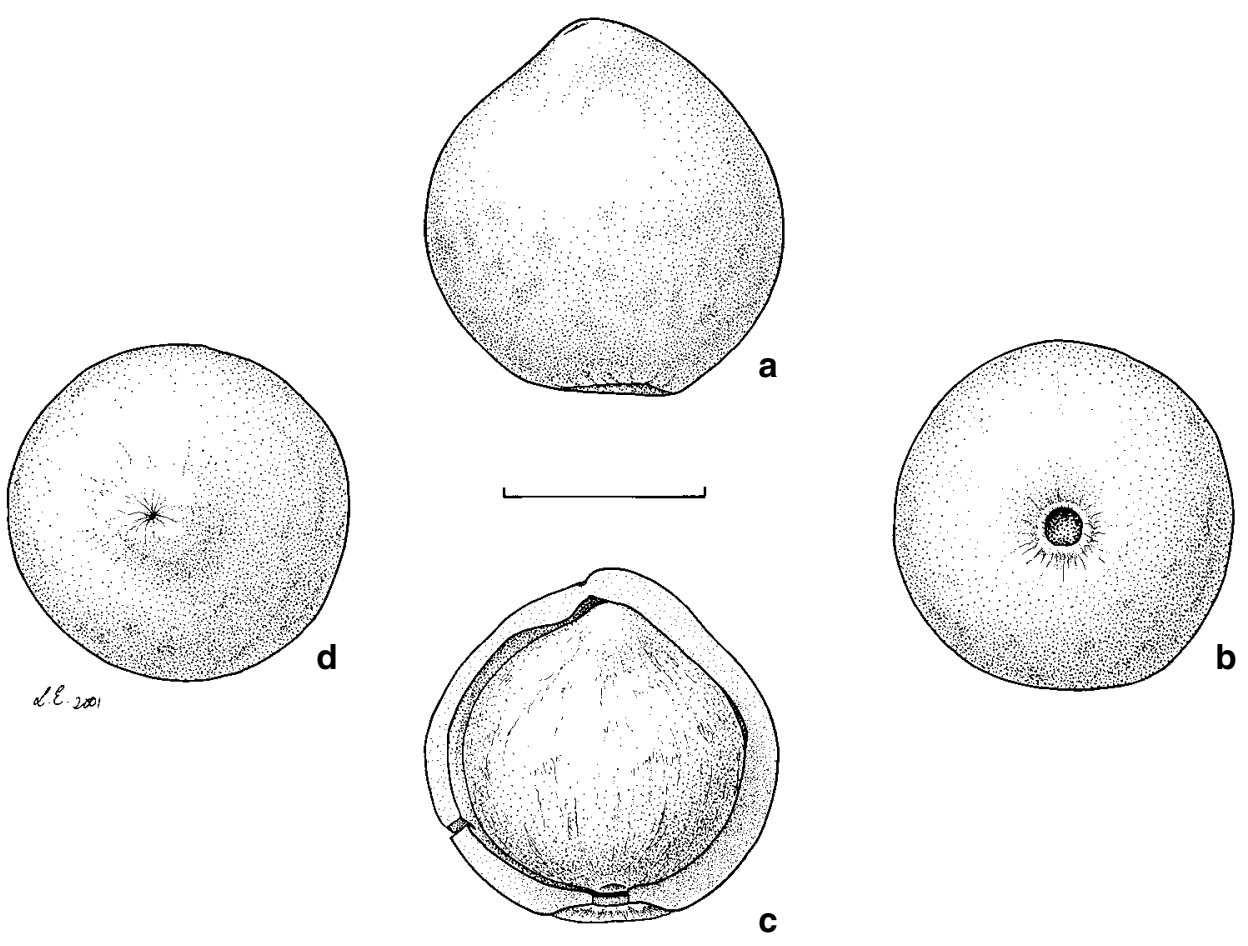

Fig. 4. Eidothea hardeniana P.H. Weston \& R.M. Kooyman. a, Whole fruit viewed from the side; b, whole fruit viewed from below; $\mathbf{c}$, fruit with exocarp half removed by a medial, longitudinal cut, showing endocarp, viewed from the side; $\mathbf{d}$, whole fruit viewed from above. From Kooyman s.n. (NSW478642). Scale bar: $\mathrm{a}-\mathrm{d}=2 \mathrm{~cm}$.

\section{Acknowledgments}

We are grateful to Alec Floyd and Dr Len Webb for assistance in interpreting label information of early specimens. John Hunter, Richard Johnstone, Damien Hofmeyer and Dr Peter Bernhardt assisted with field work. Dr Bernie Hyland kindly collected specimens from cultivated seedlings of E. zoexylocarya specially for this study. Dr Andrew Douglas provided information from unpublished studies of E. zoexylocarya as well as helpful comments on an earlier draft of the manuscript. We are grateful to the directors of BRI and MEL for providing their collections of Eidothea on loan and to QRS for donating duplicate specimens to NSW. Lesley Elkan drew the figures. Dr Peter Wilson kindly corrected our Latin description. 


\section{References}

Bentham, G. (1863) Flora Australiensis, vol. 1 (Lovell Reeve: London).

Clifford, H.T. \& Dettmann, M.E. (2001) Drupe - a term in search of a definition. Austrobaileya 6: $127-131$.

Connell, S.W. \& Ladd, P.G. (1994) Andromonoecy and fruit set in three genera of the Proteaceae. Botanical Journal of the Linnean Society 116: 77-88.

Douglas, A.W. \& Hyland, B.P.M. (1995a) Subfamily Eidotheoideae (Appendix). Flora of Australia Vol. 16: 472-473 (ABRS/CSIRO Publishing: Melbourne).

Douglas, A.W. \& Hyland, B. (1995b) Subfamily 3. Eidotheoideae. Flora of Australia Vol. 16: 127-129 (ABRS/CSIRO Publishing: Melbourne).

McCarthy, P. (1995) (ed.) Flora of Australia Vol. 16, Elaeagnaceae, Proteaceae 1 (ABRS/CSIRO Publishing: Melbourne).

Harden, G.J. (2002) (ed.) Flora of New South Wales, vol. 2, edn 2 (UNSW Press: Kensington).

Hennig, W. (1966) Phylogenetic Systematics (Illinois University Press: Urbana).

Hoot, S.B. \& Douglas, A.W. (1998) Phylogeny of the Proteaceae based on atpß and atpß-rbcL intergenic spacer region sequences. Australian Systematic Botany 11: 301-320.

McCusker, A.(1981) Glossary. Flora of Australia Vol. 1 (AGPS: Canberra).

Pitman, W.C., Cande, S., LaBrecque, J. \& Pindell, J. (1993) Fragmentation of Gondwana: the separation of Africa from South America. In P. Goldblatt (ed.) Biological Relationships Between Africa and South America (Yale Univ. Press: New Haven).

Troll, W. (1957) Praktische Einführung in die Planzenmorphologie (Veb Gustav Fischer Verlag: Jena).

Walker, B.A. \& Whelan, R.J. (1991) Can andromonoecy explain low fruit:flower ratios in the Proteaceae? Biological Journal of the Linnean Society 44: 41-46.

Weston, P.H. \& Crisp, M.D. (1996) Trans-Pacific biogeographic patterns in the Proteaceae. Pp. 215-232, in A. Keast \& S.E. Miller (eds) The Origin and Evolution of Pacific Island Biotas, New Guinea to Eastern Polynesia: Patterns and Processes (SPB Academic Publishing: Amsterdam).

Manuscript received 20 December 2001

Manuscript accepted 5 June 2002 